\title{
Role of Cancer and Chemotherapy in the Incidence of Thrombocytopenia
}

Bassam Abdul Rasool Hassan*

Clinical Pharmacy Discipline, School of Pharmaceutical Science, University of Sains Malaysia, Malaysia

\section{Introduction}

Thrombocytopenia is a term used to indicate unusual reduction or drop in platelets numbers. These platelets play a major role in clot formation during bleeding in order to block blood lost. Therefore, a reduction in platelet number will mainly lead to incidence of bleeding, which ranges from mild bleeding from small blood vessels to severe bleeding from large blood vessels. Severe bleeding in the presence of severe thrombocytopenia or when is coupled with other clotting disorders can lead to serious morbidity or death. Thrombocytopenia is a common problem experience by cancer patients, which usually is a result of the use of conventional chemotherapy, and at times, is a dose limiting factor for chemotherapy administration. About $10-25 \%$ of solid cancer patients (specifically: breast cancer, ovarian and germ cell) who were treated with intensive chemotherapy suffer from incidence of thrombocytopenia. Even though, incidence of thrombocytopenia among acute leukemia patients is higher than its incidence among other types of cancer [1-8].

\section{Levels of Thrombocytopenia}

The normal range of the platelets is between 150,000 and 450,000 cells per microliter of blood (i.e. $150-450 \times 10^{9} / \mathrm{L}$ ), while thrombocytopenia could be classified into three levels as follows:

1. ild thrombocytopenia if platelets count $<150$ and $\geq 100 \times 10^{9} / \mathrm{L}$.

2. oderate thrombocytopenia if platelets count $<100$ and $\geq 50 \times 10^{9} / \mathrm{L}$.

3. Severe thrombocytopenia if platelets count $<20 \times 10^{9} / \mathrm{L}[9,10]$.

\section{Association of Thrombocytopenia with Chemotherapy}

Thrombocytopenia is a harmful side effect of chemotherapy, since it will cause incidence of bleeding among solid cancer patients who were treated with chemotherapy from vital organ mainly the brain. Chemotherapies, specifically the antimetabolites and alkylating agents, caused thrombocytopenia by various mechanisms, either by suppressing megakaryopoiesis, i.e. bone marrow suppression or by direct damaging of the platelets [7,11-13].

\section{Thrombocytopenia and Solid Cancer}

The relationship between hemorrhage and thrombocytopenia in leukemic patient was first described in 1962. While among solid cancer patients, presence of thrombocytopenia was reported later [14]. Among those patients, i.e. solid cancer patients, the main cause for incidence of thrombocytopenia is its metastasis to bone marrow. The most frequent types of solid tumors that metastasis to bone are breast, lung and prostate cancers. These cancers when metastasized to bone marrow will lead to bone marrow suppression, resulting in neutropenia and thrombocytopenia with serious morbidity and mortality [15]. Even though the incidence of hemorrhage among solid cancer patients still consider low when it is compared with hematological malignant, unless all the above characteristic are all present [7].

\section{Conclusion}

Therefore, it is an obligate and/or recommended subject for the ongoing on preclinical studies to focus on the incidence of thrombocytopenia among cancer patients.

\section{References}

1. Dolan S (2005) Thrombocytopenia. The Royal Marsden Hospital Handbook of Cancer Chemotherapy. Brighton D, Wood M, Churchill Livingstone, London, UK.

2. De Bellis D (1999) Thrombocytopenia. The Gale Encyclopedia of Medicine. D Olendorf, Jeryan C, Boyaden K, Farmington Hills, Gale Research.

3. Miller B, De Bellis D (2005) Thrombocytopenia. The Gale Encyclopedia of Cancer 2. Longe JL. Detroit, Gale group.

4. Dolan S (2000) Haemorrhagic problems. In: Nursing in haematological oncology, Grundy M (Ed.), Elsevier Health Sciences, London, UK 339.

5. Terranova L, Gerli G, Cattaneo M (2007) Platelet disorders in the elderly. In: Blood disorders in the elderly, Bladucci L, Ershler W, de Gaetano G (Eds.), Cambridge University Press, UK 420-431.

6. Kuter DJ (2006) Thrombopoietin: Biology and potential clinical applications. In: Thrombocytopenia, McCrae KR (Ed.), Taylor \& Francis Group, New York, USA 17-51.

7. Elting LS, Rubenstein EB, Martin CG, Kurtin D, Rodriguez S, et al. (2001) Incidence, cost, and outcomes of bleeding and chemotherapy dose modification among solid tumor patients with chemotherapy-induced thrombocytopenia. J Clin Oncol 19: 1137-1146.

8. Cantor SB, Elting LS, Hudson DV, Rubenstein EB (2003) Pharmacoeconomic analysis of oprelvekin (Recombinant Human Interleukin-11) for secondary prophylaxis of thrombocytopenia in solid tumor patients receiving chemotherapy. Cancer 97: 3099-3106.

9. Lea B, Anna P, Shakuntala N, Rajeev M (2007) Thrombocytopenia related neonatal outcome in preterms. Indian J Pediatr 74: 269-274.

10. McClure MW, Berkowitz SD, Sparapani R, Tuttle R, Kleiman NS, et al. (1999) Clinical significance of thrombocytopenia during a non-ST-elevation acute coronary syndrome the platelet glycoprotein IIb/llla in unstable angina: Receptor suppression using integrilin therapy (PURSUIT) trial experience. Circulation 99: 2892-2900.

11. Zeuner A, Signore M, Martinetti D, Bartucci M, Peschle C, et al. (2007) Chemotherapy-induced thrombocytopenia derives from the selective death of megakaryocyte progenitors and can be rescued by stem cell factor. Cancer Res 67: 4767-4773.

12. Margaglione M (2005) Congenital platelet disorders. In: Postgraduate Haematology, Hoffbrand AV, Catovsky D, Tuddenham EGD (Eds.), Blackwell Publishing Ltd, Massachusetts, USA 925-936.

13. Aapro M (2004) Granisetron: An update on its clinical use in the management of nausea and vomiting. The Oncologist 9: 673-686.

*Corresponding author: Bassam Abdul Rasool Hassan, Clinical Pharmacy Discipline, School of Pharmaceutical Science, University of Sains Malaysia, 11800, Minden, Penang, Malaysia, Tel: +60164230950; E-mail: bassamsunny@yahoo.com

Received November 16, 2013; Accepted November 19, 2013; Published November 22, 2013

Citation: Hassan BAR (2013) Role of Cancer and Chemotherapy in the Incidence of Thrombocytopenia. Pharmaceut Anal Acta 4: e157. doi: 10.4172/21532435.1000e157

Copyright: (c) 2013 Hassan BAR. This is an open-access article distributed under the terms of the Creative Commons Attribution License, which permits unrestricted use, distribution, and reproduction in any medium, provided the original author and source are credited. 
Citation: Hassan BAR (2013) Role of Cancer and Chemotherapy in the Incidence of Thrombocytopenia. Pharmaceut Anal Acta 4: e157. doi: 10.4172/2153-2435.1000e157

Page 2 of 2

14. Elting LS, Cantor SB, Martin CG, Hamblin L, Kurtin D, et al. (2003) Cost of chemotherapy-induced thrombocytopenia among patients with lymphoma or solid tumors. Cancer 97: 1541-1550.
15. Kiliçkap S, Erman M, Dinçer M, Aksoy S, Harputluoğlu H, et al. (2007) Bone marrow metastasis of solid tumors: Clinicopathological evaluation of 73 cases. Turk J Cancer 37: 85-88. 